\title{
THE EFFICACY OF RECIPROCAL TEACHING METHOD IN TEACHING READING COMPREHENSION TO EFL STUDENTS
}

\author{
Qurrotul A'yun \\ qurrotulayun@gmail.com \\ University of Islam Malang \\ Muhammad Yunus \\ m.yunus@unisma.ac.id \\ University of Islam Malang
}

\begin{abstract}
The article aims to investigate the efficacy of Reciprocal Teaching Method (RTM) on reading comprehension to EFL students. The subject of the study was two classes from the second grade students of Ilmu Agama Islam (IAI) in Probolinggo. There were 44 students emerging from XI IAI 1 and XI IAI 2 which consisted of 22 each. Nonrandomized sampling was chosen to select the group. To decide the groups into control and experimental, coin was used. The XI IAI 1 class then became the experimental group (taught using reciprocal teaching method), meanwhile the XI IAI 2 was the control group (taught using conventional as it is). Both classes acquired mixed levels of reading achievement. It means that both classes were at the same level of reading comprehension. After the treatment, it revealed that those who were taught using RTM gained better result than those were taught using the conventional one.
\end{abstract}

Key Words: Reciprocal Teaching Method, Reading Comprehension, Conventional Strategy

\section{BACKGROUND}

Reading is viewed from various ways. In the classroom, reading is considered as the most important activity, not only as a source of information and pleasurable activity, but also as a means of extending one's knowledge of language (Yunus \& Parlindungan, 2012). In addition, Anderson (2000) claimed that reading is the activity or process to understand and construct meaning which involves the interaction between text and the reader.

Reading, in Indonesian context, is classified into two types: initial reading and reading comprehension (Cahyono \& Widiati, 2006, p.36). Further Cahyono and Widiati (2006) explained that initial reading is an effort made by those who have not been able to read to learn reading (e.g., how to read the alphabets and combination of letters or simple words), whereas reading comprehension is an activity aimed to understand the messages of a particular text (Williams, 1998 as cited by Cahyono \& Widiati, 2006, p.37). Therefore, the teaching of reading as a foreign language (EFL reading) in Indonesia can be generally included in the teaching of reading comprehension (Cahyono 
\& Widiati, 2006, p.37). It means that the activities of reading in the classroom put emphasis on understanding texts emerging from texts.

Pertaining to the practice of EFL reading, there are some models of the process of reading that are widely known: the bottom-up model, the top-down model, and the interactive model (Silberstein, 1987 as cited in Cahyono \& Widiati, 2006, p.39). According to the bottom-up model, reading is a process of manipulating phonemegrapheme relationships as described by a structural linguist Leonard Bloomfield (Dubin \& Bycina, 1991).

According to Harmer (1991:190),"reading is an exercise dominated by the eyes and brain." Meanwhile, Nunan (1991:64) argued that reading can be defined as a habit of the reader to do a process such as decoding written symbol, word, clause and sentence. The top-down model views reading as a process of reconstructing meaning, and it stresses comprehension of units of meaning larger than words and phrases. The proponents of this model include Kenneth Goodman and Frank Smith (Dubin \& Bycina, 1991). The interactive model of the process of reading, puts together the earlier two models of reading, the bottom-up and the top-down. According to this model, reading involves the interplay of all meaning gathering activities. This interactive theory acknowledges the role of previous knowledge and prediction, but, at the same time, reaffirms the importance of rapid and accurate process of the actual words of the text (Carrell, Devine, \& Eskey, 1988; Dubin \& Bycina, 1991).

There are three levels of reading comprehensions (Rodli, 2015 as cited in Nimasari, 2016, p.120). Those are literal comprehension, inferential comprehension, critical reading or creative reading. Literal reading comprehension relates to finding information stated in the text, meanwhile inferential reading comprehension is about connecting ideas between one to another paragraph in a text. Different from those levels, critical and creative reading include one's critical thinking and awareness towards implicit ideas beyond the text. In line with this, Cahyono and Mukminatien (2011:58) stated that reading comprehension is the process of constructing meaning which involves readers' schemata. However, the readers integrate the meaning from visual information and non-visual information because they have an active process. It can be concluded that comprehension only focuses on understanding, so the reader can understand the specific information and the general information that they read because they succeed to construct the meaning of the text.

The theory of reading emerges into three; text structure theory, schemata theory, and metacognitive theory. Meyer (1975 as cited in Cahyono \& Widiati, 2006, p. 40) stated that the structure of a text resembles a tree structure, where the more general information subsumes the more specific information in the text. Accordingly, the location of information in a text structure relates to the level of ease in remembering the information. Information which is more general (which is located in the upper level of the structure) is remembered more easily than the more specific information (which is located in the lower level of the structure). Meanwhile, the schemata theory says that a potential reader comes to read a text with something in his/her mind or memory, which is called 'schema', which means 'pre-existent knowledge of the world' (Cook, 1989 cited in Harmer, 2001: 199 as cited in Cahyono \& Widiati, 2006, p. 41). Further Carrell (1988) argues that there are three kinds of schemata: linguistic schemata (i.e., prior linguistic knowledge), content schemata (i.e., prior background knowledge), and formal 
schemata (i.e., knowledge of text structure). The metacognitive is about knowledge or regulation of cognition pertaining to planning, monitoring, and evaluating (Chaudron, 1988: 133 as cited in Cahyono \& Widiati, 2006, p 42). According to Wade and Reynolds (1989), developing metacognitive awareness is an essential part of effective reading strategy instruction. Accordingly, effective and efficient readers are those who not only know what to read in order to comprehend a text, but also know how best to approach the text before, during, and after reading it.

Reading involves a complex process. To comprehend of the whole text, readers need to decode text and make interpretations. So, they have guideline in apprehending the text; also, their background knowledge will be on. To construct the meaning of the text, the readers must have some various strategies, methods and skills to interact with the text because they need to monitor and maintain their understanding of the text. Therefore, they must have skills to build meaning of the text as the result of their comprehension must appropriate with the context OECD (in Gay, 2005:1).

Choo, Eng and Ahmad (2011) stated that most of students face challenge when they read the text. They cannot build the meaning of the text because they only read the text without trying to know and comprehend the vocabulary that is unfamiliar for them. There are three main factors to overcome the students' problem. Those are: 1) the students' attention of the text; 2) their prior knowledge; 3) an active strategies to enhance their ability in apprehending the text; and 4) the strategy to help them in lack of comprehension (Palinscar \& Brown 1984:118).

Due to this fact, some research found that many students are reluctant in the process of reading comprehension in the class even though reading is considered to be important language skill. Pertaining to this, Kweldju (1996 as cited in Cahyono \& Widiati, 2006, p.49) found that students were not interested in reading their content area textbooks although they thought such textbooks were useful. She stated that reasons behind this lack of interest included students' limited background knowledge, inability to understand the content of the text, and complicated organizational structure of the text. Rukmini (2004 as cited in Cahyono \& Widiati, 2006, p.49) hypothesized that the reasons behind students lack of interest in reading was students' unfamiliarity with various genres employed in reading texts. In her report of genre analysis, she found that most reading texts used in senior high schools were anecdote and descriptive texts. Firmanto (2005 as cited in Cahyono \& Widiati, 2006, p.49) found that reading was considered a boring and stressful activity because of some factors such as unsuitable texts (e.g., due to the text length or unfamiliar vocabularies), teachers scarcity in employing pre-reading activities (e.g., explaining some difficult words or activating the students prior knowledge), and monotonous post-reading activities (e.g., answering questions based on the texts and retelling the texts).

To have better reading comprehension, teachers should have a method which is prepared well before it is applied in the classroom. The method will help students to make them easily in comprehending the text, and make them motivated to more focus in their learning activity. Furthermore, the researcher chose reciprocal teaching method for students' reading comprehension.

Palinscar (1986) stated that a reciprocal teaching method is created to increase the level of students' understanding of a reading comprehension which involves the interaction between students and teacher and students and students so that everyone 
becomes an active learner. Thus, they will give response to each other. Meanwhile, Manohar as cited in Norasih 2011, p.4), the reciprocal teaching method does not only support learners in understanding reading text but also in providing the opportunities for students to monitor themselves in their learning and thinking process. The purpose of reciprocal teaching method is to facilitate students in communicating and helping each other in their respective group for comprehending the text that is given by teacher.

Palinscar and Brown (1984) explained that reciprocal teaching method consists of four strategies that must be applied in learning activity to make a successful comprehending the text. Those are predicting, clarifying, questioning, summarizing, and that will be described as follow. Quoting from Palinscar and Brown (1984), the four strategies of reading comprehension are explained as follow.

Predicting is a guessing activity of a topic, picture or words. Before reading a text, learners have been able to deduce the content of the text by linking their experience. In addition, students will also be able to predict what will be discussed in the next paragraph related to the text they have read. After reading the text, students can combine their prior knowledge with the information they have read at the time so that it can confirm whether their prediction about the text is right or not.

Clarifying is to identify a vocabulary that is unfamiliar for them and difficult to find. In addition, clarifying is also used to justify the pronunciation of words so that learners must think critically to find a main idea and sub main point of the text. Such problems are often encountered by learners because the text is usually found the concept or structure of text that is unclear while reading. Therefore, learners need clarification to make everything clear in capturing the meaning of the text. This clarification can provide motivation for learners to overcome the problems they faced.

Questioning is based on the content of the text that is read, so students must concentrate on finding a key idea, and identifying information and facts from main idea of the text. This question can measure the level of students' deepening of the passage and can provide evidence to the teacher that the students have been able to construct and understand the meaning by creating his own question. This question also serves to guess the questions that come from the teacher.

Summarizing is a process of identifying what is important information and insignificant information of a text so that learners can reveal the main ideas and facts of a text by using their own language. Summarizing is also a form of the constructed meaning that is generated by the students and made into a concise statement which is important information from the text. It aims to ensure that students really understand the content of the text. In addition, summarizing can also encourage the enthusiasm of students in apprehending text that has a specific meaning.

This four reading strategies are useful tools for students not only help to construct meaning from the text but also help to monitor their reading, so they really understand what they are reading. And the four strategies mentioned earlier are in line with the theory of schemata proposed by Harmer (2011) and metacognitive theory of reading as proposed by Chaudron, 1988, p.113). Furthermore, RTM can facilitate learners to setting the focus, disturbance, dialogue, development, resolution, and morale as stated by Lian (2017).

Therefore, the article aims at investigating the efficacy of reciprocal teaching method affected on reading comprehension ability students. The hypothesis of this study 
emerged that students who are taught using reciprocal teaching method have better reading comprehension than those taught using conventional method.

\section{METHOD}

The research design of this study was experimental design. In experimental research design, the researcher was as active agent rather than a passive observer. Experimental research is concerned with the examination of the effect on an independent variable on dependent variable. The independent variable is manipulated through treatment or intervention that is RTM, meanwhile the dependent variable is EFL reading comprehension.

Quasi-experimental design was applied with pre-test and post-test. Since the classroom is not fully handed by the researchers, this design is appropriated to choose. The pre-test was aimed to ensure that the two groups were equally in reading comprehension, meanwhile the post-test was used to compare the score of the two groups to conclude which group gain better score and whether the score is significantly different or not.

The population of this research was all of the classes of the second grade students in MA. Zinul Hasan 1 Genggong, Probolinggo. There were nine classes. Six classes were female and three classes were male. Overall, there are three classes of for science major consisting 1 male class and 2 female classes. Three classes of social studies consisting 1 male class and 2 female classes. And three classes of IAI consisting 1 male class and 2 female classes. Each class consists of 25 students maximum. Overall there are 215 students. The sample was two classes from second grade IAI female by using shuffle, so the entire sample was 44 students. Therefore, there were XI IAI 1 and XI IAI 2, both of them are from female class, where the researcher used coin to divide which one being control group and experimental group. The result was XI IAI 1 was the experimental group, and XI IAI 2 was the control group which both of class had mix levels of reading achievement.

To ensure the ability of the students' reading comprehension, the researcher administered pretest and posttest. The pretest was the test that was conducted before giving the treatment in the research. Meanwhile, the posttest was administered after the treatment. The researchers developed the test specification. The test materials were based on the materials given in the class. There were 30 items emerging hortatory exposition text. The test is an objective test with four options. The specification of the test covers finding main idea, interpreting the word, synonym, and knowing detail information.

The test items were validated by the expert of reading skill. After some revision finally the items are administered in the class. Furthermore, the research was done as long as four weeks. Two weeks was for treatments, and other weeks was for giving pretest and post-test.

On the other hand, the researchers analyzed reliability of the test by using Split Half. The coefficient of reliability used Spearman Brown Formula. 


\section{FINDINGS}

First of all is provided the level of reliability of the test. The classification of coefficient and result of reliability can be seen in Table 1, Table 2, and Table 3 .

Table 1 The Classification Coefficient

\begin{tabular}{ll}
\hline Index of Correlation Coefficient & \multicolumn{1}{c}{ Level of Reliability } \\
\hline 1.00 & Perfect reliability \\
$0.88-0.999$ & Very high \\
$0.600-0.799$ & High \\
$0.400-0.599$ & Enough \\
$0.200-0.399$ & Low \\
$0.000-0.199$ & Very low \\
\hline
\end{tabular}

Table 2 The Result of Reliability Test (pre-test) by Using Split Half

\begin{tabular}{|c|c|c|c|}
\hline \multicolumn{4}{|c|}{ Reliability Statistics } \\
\hline \multirow[t]{5}{*}{ Cronbach's Alpha } & Part & Value & .674 \\
\hline & & $\mathrm{N}$ of Items & $16^{\mathrm{a}}$ \\
\hline & Part & Value & .515 \\
\hline & & $\mathrm{N}$ of Items & $15^{\mathrm{b}}$ \\
\hline & Tot & of Items & 31 \\
\hline \multicolumn{3}{|c|}{ Correlation Between Forms } & .893 \\
\hline Spearman-Brown & \multicolumn{2}{|c|}{ Equal Length } & .944 \\
\hline Coefficient & \multicolumn{2}{|c|}{ Unequal Length } & .944 \\
\hline \multicolumn{3}{|c|}{ Guttman Split-Half Coefficient } & .773 \\
\hline $\begin{array}{l}\text { a. The items are: soa } \\
\text { soal10, soal11, soal }\end{array}$ & 2, so & $\begin{array}{l}\text { al4, soal5 } \\
\text { soal15. }\end{array}$ & al9, \\
\hline
\end{tabular}

Table 3 The Result of Reliability Test (post-test) by Using Split Half

\begin{tabular}{|c|c|c|}
\hline \multicolumn{3}{|c|}{ Reliability Statistics } \\
\hline \multirow[t]{5}{*}{ Cronbach's Alpha } & Part 1 & .657 \\
\hline & $\mathrm{N}$ of Items & $16^{\mathrm{a}}$ \\
\hline & Value & .491 \\
\hline & $\mathrm{N}$ of Items & $15^{\mathrm{b}}$ \\
\hline & Total $\mathrm{N}$ of Items & 31 \\
\hline Correlation Between Forms & & .805 \\
\hline Spearman-Brown & Equal Length & .892 \\
\hline Coefficient & Unequal Length & .892 \\
\hline \multicolumn{2}{|c|}{ Guttman Split-Half Coefficient } & .760 \\
\hline
\end{tabular}

a. The items are: soal17, soal18, soal19, soal20, soal21, soal22, soal23, soal24, soal25, soal26, soal27, soal28, soal29, soal30, total. 
b. The items are: soal1, soal2, soal3, soal4, soal5, soal6, soal7, soal8, soal9, soal10, soal11, soal12, soal13, soal14, soal15.

Based on the result on Table 2 and 3, it could be known that the coefficient of reliability of pre-test (0.773) and post-test (0.760), so the conclusion was the instruments which were used in this study had a high value. It was based on the classification criteria of reliability 0.600-0.799 in the high level.

The data of obtained from the test was analyzed using t-test. According to Mistar (2013), "the t-test is used when the researcher compares two means to find the significance of the difference between the two mean." The researchers used independent t-test to analyze the data because the subject of control group and experimental group was not significantly different in term their ability in reading comprehension. In this case, SPSS 16 for analyzing the data was used.

In analyzing the data, the researchers focused on analyzing the data such as analyzing the test of normality (pre-test) from two groups, testing the homogeneity of covariance (pre-test and post-test) from two groups, comparing independent samples test between experimental group and control group, testing the descriptive statistic and analyzing the hypothesis testing by using SPSS version 16.

Table 4 The Result Test of Normality for Pre-test (Experimental Group)

\begin{tabular}{|c|c|c|c|c|c|c|}
\hline \multicolumn{7}{|c|}{ Tests of Normality } \\
\hline & \multicolumn{3}{|c|}{ Kolmogorov-Smirnov $^{\mathrm{a}}$} & \multicolumn{3}{|c|}{ Shapiro-Wilk } \\
\hline & Statistic & Df & Sig. & Statistic & Df & Sig. \\
\hline IAI1 & .160 & 22 & .147 & .943 & 22 & .223 \\
\hline
\end{tabular}

Table 5 The Result Test of Normality for Pre-test (Control Group)

\begin{tabular}{|c|c|c|c|c|c|c|}
\hline \multicolumn{7}{|c|}{ Tests of Normality } \\
\hline & \multicolumn{3}{|c|}{ Kolmogorov-Smirnov ${ }^{\mathrm{a}}$} & \multicolumn{3}{|c|}{ Shapiro-Wilk } \\
\hline & Statistic & Df & Sig. & Statistic & Df & Sig. \\
\hline VAR00001 & .119 & 22 & $.200^{*}$ & .950 & 22 & .312 \\
\hline \multicolumn{7}{|c|}{ a. Lilliefors Significance Correction } \\
\hline
\end{tabular}

Table 4 and 5 showed that it could be seen that the significant value of experimental group was 0.147 and for control group was 0.200 . Therefore, in terms of the significant value between experimental and control group was not quite different. It could be concluded that the significant value of experimental group (0.147) and control group (0.200) was higher than 0.05 , so $H_{0}$ from experiment and control group was accepted because the data from experimental and control group was normally distributed. 
Table 6 The Result Test of Homogeneity (pre-test)

Test of Homogeneity of Variances

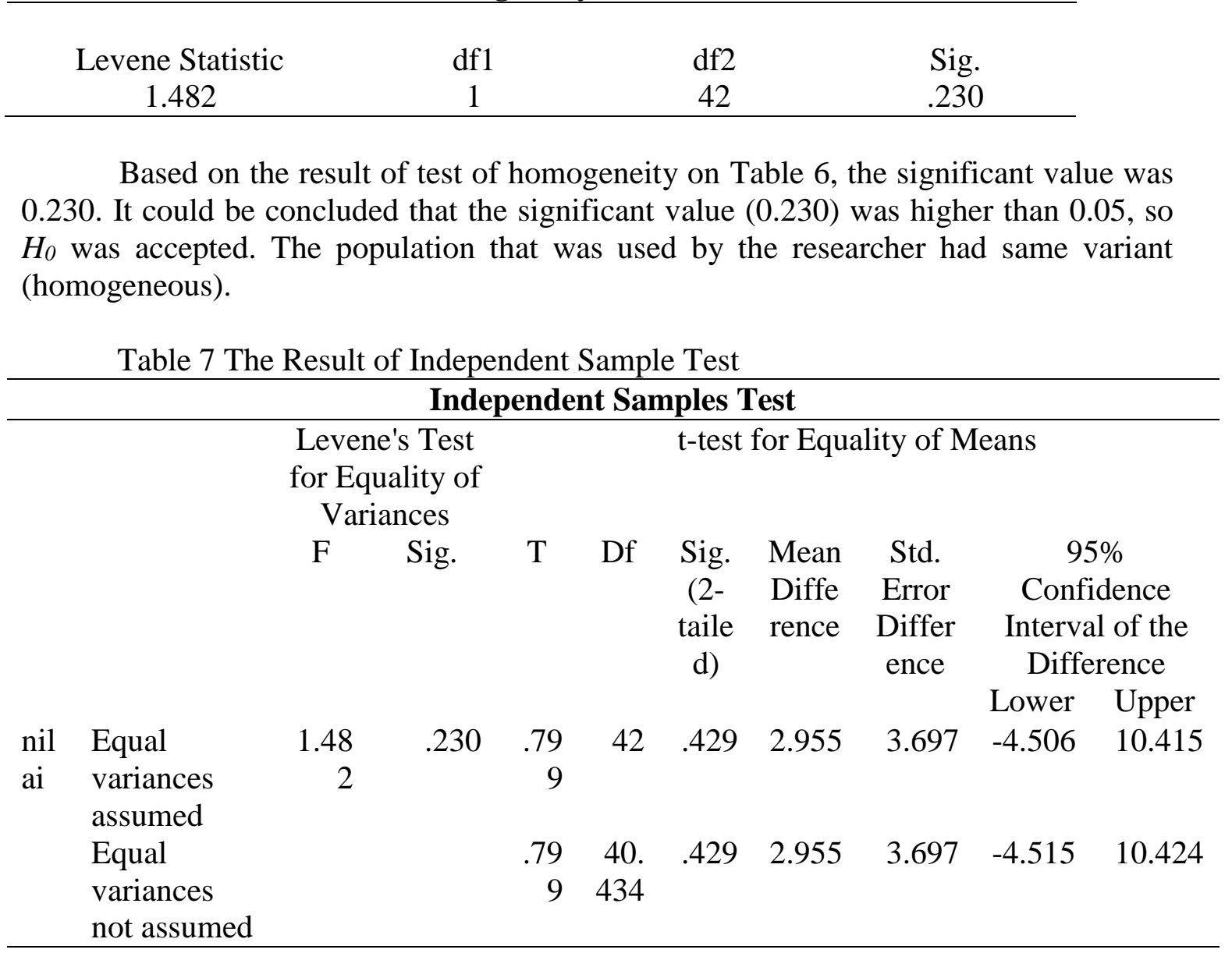

The above-table was the result of independent sample T-test of pre-test. The researcher used independent sample T-test for pre-test to analyze the data. The $t$ value of both groups was .799. Then, the $d f$ of experimental group was 42; the control group was 40.434. The significant of two tailed from both of groups was .429 , and it was higher than 0.05 . The mean difference from both of groups was 2.955 . It indicated that both groups had the same scores in pre-test.

Table 8 The Result Test of Homogeneity (post-test)

\section{Test of Homogeneity of Variances}

\begin{tabular}{cccc}
\hline $\begin{array}{c}\text { Levene } \\
\text { Statistic }\end{array}$ & df1 & df2 & Sig. \\
3.213 & 1 & 42 & .080 \\
\hline
\end{tabular}

Based on the result of test of homogeneity on the table 8 , the significant value was 0.80 . It could be concluded that the significant value $(0.80)$ was higher than 0.05 . 
$H_{0}$ was accepted, so the population that was used by the researcher had same variant (homogeneous).

Table 9 The result of descriptive statistic

\begin{tabular}{|c|c|c|c|c|c|c|c|}
\hline \multicolumn{8}{|c|}{ Descriptive Statistics } \\
\hline & $\mathrm{N}$ & $\begin{array}{l}\text { Minim } \\
\text { um }\end{array}$ & $\begin{array}{l}\text { Maxim } \\
\text { um }\end{array}$ & Sum & Mean & $\begin{array}{c}\text { Std. } \\
\text { Deviation }\end{array}$ & $\begin{array}{c}\text { Varian } \\
\text { ce }\end{array}$ \\
\hline Kelas control & 22 & 55.00 & 84.00 & $\begin{array}{r}1587.0 \\
0\end{array}$ & $\begin{array}{r}72.136 \\
4\end{array}$ & 9.42790 & 88.885 \\
\hline Kelas & 22 & 64.00 & 92.00 & 1761.0 & 80.045 & 7.43529 & 55.284 \\
\hline $\begin{array}{l}\text { experiment } \\
\text { Valid N } \\
\text { (listwise) }\end{array}$ & 22 & & & 0 & 5 & & \\
\hline
\end{tabular}

Based on Table 9, the researchers analyze the result of descriptive statistic of this study. The researcher used XI IAI 1 as an experimental group and XI IAI 2 as a control group which consisted of 22 students of each class. On the control group showed that the minimum score that students got before getting the treatment was 55.00, and for experimental group was 64.00. Furthermore, experimental and control groups were not satisfying the KKM (75.00). The maximum score of control group after getting the treatment was 84.00 , and for experimental group was 92.00. Then, the mean score of control group was 72.14; also, the mean score of experimental group was 80.05. It could be concluded that experimental group had the higher mean score than control group; also, the mean score of experimental group had satisfied based on the KKM (75.00) of the school.

Table 10 The Result of Hypothesis Testing

\begin{tabular}{|c|c|c|c|c|c|c|c|c|c|c|}
\hline \multicolumn{11}{|c|}{ Independent Samples Test } \\
\hline & & \multicolumn{2}{|c|}{$\begin{array}{c}\text { Levene's Test } \\
\text { for Equality } \\
\text { of Variances }\end{array}$} & \multirow{3}{*}{$\mathrm{t}$} & \multirow{3}{*}{ Df } & \multicolumn{5}{|c|}{ t-test for Equality of Means } \\
\hline & & $\mathrm{F}$ & Sig. & & & $\begin{array}{l}\text { Sig. } \\
(2- \\
\text { taile } \\
\text { d) }\end{array}$ & $\begin{array}{l}\text { Mea } \\
n \\
\text { Diffe } \\
\text { renc }\end{array}$ & $\begin{array}{l}\text { Std. } \\
\text { Error } \\
\text { Differ } \\
\text { ence }\end{array}$ & $\begin{array}{r}\text { Con } \\
\text { Inter } \\
\text { Dift }\end{array}$ & $\begin{array}{l}\% \\
\text { dence } \\
1 \text { of the } \\
\text { rence }\end{array}$ \\
\hline & & & & & & & $\mathrm{e}$ & & $\begin{array}{c}\text { Lowe } \\
r\end{array}$ & Upper \\
\hline \multirow[t]{6}{*}{ Nilai } & Equal & 3.21 & .080 & 3.0 & 42 & .004 & 7.90 & 2.560 & 2.743 & 13.075 \\
\hline & $\begin{array}{l}\text { variances } \\
\text { assumed }\end{array}$ & 3 & & 90 & & & 9 & & & \\
\hline & Equal & & & 3.0 & 39. & .004 & 7.90 & 2.560 & 2.735 & 13.084 \\
\hline & variances & & & 90 & 83 & & 9 & & & \\
\hline & not & & & & 6 & & & & & \\
\hline & assumed & & & & & & & & & \\
\hline
\end{tabular}


By analyzing the data above, the researchers found the average score of the experimental group was 80.05 while the average score of the control group was 72.14. From the result of the independent T-test above, it was found from both of the groups that the value of $t=3.090$ while the significant (2-tailed) was .004; also, it was lower than 0.05. Thus, $H_{0}$ was rejected. The last step was testing the hypothesis. After checking out the table, it was found that $t$ critical was 3.090 while $d f$ was 42 , and critical value at level of significant 0.05 was 2.080. The $t$ (3.090) was higher than critical value (2.080) at level significant 0.05. Based on what had been stated above, the researchers concluded that students taught by using reciprocal teaching method was better than the students taught using the conventional method.

\section{DISCUSSIONS}

Based on the research finding of this study, the researcher claimed that reciprocal teaching method had significant effect on reading comprehension to EFL students. To prove of the research finding, Bess as cited (in Carter 1997) argued that reciprocal teaching was an instructional method to improve students' understanding, especially in improving students' reading comprehension. In addition, this method provided various strategies to make it easier for students to understand the text so that students and teachers could easily master and understand this method to be applied.

As quoted from Palinscar (1986), he declared that in predicting, the students should predict or guess what the content was about through topic and picture. Next, in clarifying, the students clarified the unrecognized vocabulary. Then, in questioning, the students got questions from the teacher related to measure their level of comprehension of the text. The last, in summarizing, the students were asked to conclude or summarize the content of the text by using their own word. Those were some reasons why reciprocal teaching method was effective on reading comprehension ability students.

The practice in the classroom is divided into pre-reading, while-reading, and post-reading activities emerging the four steps of RTM. The reading process should be started with respecting the prior experience and knowledge possessed by the students. The reading materials and topics that used and discussed in the classroom should be attempted as close as possible with the students' lives, should be interesting for students, and suitable with the students' language proficiency. There should be enough room for students to express their opinions. Students should be encouraged to respond to the questions about particular reading materials.

These findings support the previous finding with related topic. To mention for example, Soonthornmanee (2002) investigated metacognitive awareness and comprehension monitoring as employed by RTM involving summarization, questiongeneration, clarification, and prediction. Following the procedures of RTM by adding guided questions to his study, he revealed that RTM helped the less-skilled readers and also improve their reading comprehension.

In addition to that, Alfassi (1998) investigated the effects of strategy instruction on reading comprehension. His result confirms the effectiveness of RTM in teaching reading. As he mentioned in his paper that the results of this study support the implementation of strategy instruction aimed at fostering self-monitoring skills within a reading comprehension curriculum. The results demonstrate that reciprocal teaching is a viable instructional technique that can be implemented successfully within large, intact, 
remedial reading high school classes as part of the curriculum. These findings further support the practice of teaching strategies in a group setting in addition to providing instruction adjusted to student difficulties. This study lends additional support to recent research on the reading process that views the development of reading comprehension as a process of emerging expertise, where readers develop strategies that help them to construct meaning from text and teaching is viewed as an active, constructive process in which teachers and students mediate and negotiate the meaning of their reading (Alfassi, 1998, p. 326).

Finally, after analyzing and reviewing methods which were discussed in the previous sub topics, it showed that RTM has significantly affected to students' reading comprehension ability of the second grade of MA. ZAINUL HASAN 1 Genggong, Probolinggo. This result is not conflicting to the previous findings done by other researchers. It is strongly believed that RTM is valuable method to be implemented in the EFL reading especially in Indonesian context as it is engaging students to optimally use schemata and metacognitive theory. Therefore, emerging questions in reading process (monitoring) facilitate EFL readers to aware of their reading activities.

\section{CONCLUSIONS}

The study showed that there was a significant difference effect on reading comprehension to EFL students of those taught using reciprocal teaching method and those taught using conventional; also, it gave a higher effect on reading comprehension ability, especially at second grade students. The researcher had already proven it. By using reciprocal teaching method, students could improve their reading comprehension to EFL students. There is a challenge emerges in this study that reading habit performed by the students is still low. There is a need for further investigation to motivate students in developing their habit of reading. In addition to that, there is also need to investigate further to the comprehension level 3 that is critical or creative reading. This is based on the need when the students of senior high school want to continue to higher education. It will be better if the concern is more to critical reading than to literal or inferential comprehension.

\section{REFERENCES}

Alfassi, M. (1998). Reading for Meaning: Ther Efficacy of Reciprocal Teaching in Fostering Reading Comprehension in High School Students in Remedial Reading Classes. American Educational Research Journal, Vol. 35 (2), pp. 309-332. Anderson, J Charles. 2000. Assesing Reading. Cambridge University Press.

Basuki, I., H. (2015). Assessment Pembelajaran. Bandung: Remaja Osdakarya Offset. Cahyono, B. Y., \& Widiati, U. (2006). The teaching of EFL reading in the Indonesian context: The state of the art. TEFLIN Journal, 7(1), 36-58. 
Cahyono, B.Y. \& Mukminatien, N. (2011). Techniques and Strategies to Enhance English Language Learning. Malang: State University of Malang Press.

Carrell, P. L., Devine, J., \& Eskey, D. E. (Eds.) 1988. Interactive approaches to second language reading. Cambridge: Cambridge University Press.

Carrell, P. L. 1988. Introduction. In P. L. Carrell, J. Devine, \& D. E. Eskey (Eds.), Interactive approaches to second language reading (pp. 1-7). Cambridge:

Cambridge University Press.

Carter, C., J. (1997). Why Reciprocal Teaching? (online), (http://www.ascd.org/publications/educationalleadership/mar97/vol54/num06/W hy-Reciprocal-Teaching\%C2\%A2.aspx, accessted in 28 March 2017)

Choo, T, O, L., Eng, T, K., \& Ahmad, N. (2011). Effcets of Reciprocal Teaching Strategies. The reading matrix. Vol 11 (2): 140-148.

Cresswell, J. (2012). Research Design Pendekatan Kualitatif, Kuantitatif, dan Mixed; Cetakan ke-2, Yogyakarta: Pustaka Pelajar.

Dubin, F., \& Bycina, D. 1991. Academic reading and the ESL/EFL teacher. In M. Celce-Murcia (Ed.), Teaching English as a second or foreign language( $2^{\text {nd }}$ ed.) (pp. 195-215). Boston: Heinle \& Heinle.

Gay, L. R. (1992). Educational Research ( $4^{\text {th }}$ Ed). New York:Merril.

Harmer, J. (1991). The Practice of English Language Teaching. Longman: Third Edition

Kirk, R. E. (1995). Experimental Design: Procedures for the Behavioral Sciences $\left(^{\text {rd }}\right.$ edn). Pacific Grove, CA: Brooks/Cole.

Lian, A. 2017. Reading for Emotion with ICT Tools. Chen, W. et al. (Eds.) (2017). Proceedings of the $25^{\text {th }}$ International Conference on Computers in Education. New Zealand: Asia-Pacific Society for Computers in Education

Mistar. J. (2013). Hand out Statistic for Language Teaching Studies. Malang. University of Islam Malang Press.

Nimasari, E., P. (2016). Critical Discourse Analysis in Teaching Reading. Journal on English as a Foreign Language, Vol. 6 (2), pp. 199-130.

Norasih, Ni K. (2011). The Influence of Reciprocal Teaching Learning Model on Reading Comprehension in Terms of the Concept Students' Academic, (online), (http://download.portalgaruda.org/article.php?article=259102\&val=7031\&title, accessted in 7 April 2017)

Nunan, D. (1991). Language Teaching Methodology. Prentice Hall International English Language Teaching.

OECD. (1999). Measuring student knowledge and skills: A framework for assessment. Paris: OECD.

Palincsar, A. \& Brown, A. (1984). Reciprocal teaching of comprehension-fostering and comprehension-monitoring activities. Cognition and Instruction. Vol 1 (2): 117175.

Palinscar A. (1986). Reciprocal Teaching. Teaching/Learning Strategies.

Silberstein, S. (1987). Lets take another look at reading: Twenty-five years of reading instruction. Language Teaching Forum, 25(4):18-35.

Soonthornmanee, R. (2002). The Effect of the Reciprocal Teaching Approach on the Reading Comprehension of EFL Students. RELC Journal, Vol. 33 (2), pp. 125 141 . 
Wade, S. E., \& Reynolds, R. E. (1989). Developing metacognitive awareness.

Journal of Reading, 33(1):6-13.

Yunus, M. \& Parlindungan, F. (2012). Challenging Students In Academic Controversy

To Fosterexcellent Reading Literacy. Online, retrieved from

https://www.academia.edu/10349998/challenging_students_in_academic_controv ersy_to_foster_excellent_reading_literacy, Accessted in 4 July 2017 